\title{
The impact of web marketing on corporate social responsibility (CSR) and firms' performance
}

Impact of web marketing on CSR

\author{
Mohammed Muneerali Thottoli \\ University of Nizwa, Nizwa, Oman, and \\ K.V. Thomas \\ Marian College (Autonomous), Kuttikkanam, India
}

\begin{abstract}
Purpose - The current study seeks to examine the impact of web marketing (through the company's website) on corporate social responsibility (CSR) and firms' performance across companies listed in the Muscat Stock Exchange (MSX), Oman.

Design/methodology/approach - This research analyses qualitative and exploratory data taken from companies' website, annual reports (the financial year 2019), Google search and CSR report from 69 out of total 117 listed companies in the MSX to analyze the impact of web marketing on CSR and firms' performance proxied by return of assets (ROA), return of equity (ROE) and Tobin's Q (TQ).

Findings - Web marketing on CSR positively affects firms' performance. Especially, the positive effect of web marketing on firms' performance is stronger for listed companies. Web marketing enhances financial performance proxied by ROA, ROE and TQ.

Practical implications - The research findings provide new insights that are able to enlighten governing bodies in Oman to make standardized compulsory CSR spending (say, $0.5 \%$ on profit after tax) by listed companies in MSX.

Originality/value - This research presents evidence that web marketing on CSR can increase firms' performance and brand image among stakeholders. This is the first study to examine the impact of web marketing on CSR and firms' performance using empirical data in Oman.
\end{abstract}

Keywords Corporate social responsibility, CSR, Web marketing, Firms' performance, Muscat stock exchange, Oman

Paper type Research paper

\section{Introduction}

Corporate social responsibility (CSR) operations in any business organization meet its commercial, ethical, legal and public expectations. CSR of an organization has become crucial since the organization is likely to satisfy certain obligations to the stakeholders and society in which it functions. Company's approach toward employees and who feel recognized by their employer to motivated to be innovative in their skillset. The increased social value of an organization by engaging CSR builds loyalty and brand image among customers. Constant CSR engagement positions any organization as a leader and makes public attention. CSR impacts a company's reputation, brand equity or brand image (Özcan and Elçi, 2020; Srivastava, 2019). Employees' group and environment-focused social responsibility have created improved trust in the organization (Boğan and Dedeoğlu, 2019). CSR operational performance revealed that improved organization's corporate soundness, an increase of total

(C) Mohammed Muneerali Thottoli and K.V. Thomas. Published in Rajagiri Management Journal. Published by Emerald Publishing Limited. This article is published under the Creative Commons Attribution (CC BY 4.0) licence. Anyone may reproduce, distribute, translate and create derivative works of this article (for both commercial and non-commercial purposes), subject to full attribution to the original publication and authors. The full terms of this licence maybe seen at http://creativecommons. org/licences/by/4.0/legalcode

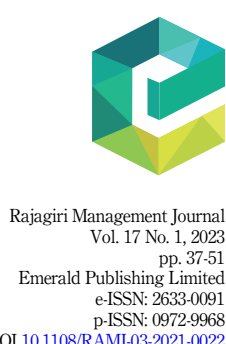

DOI 10.1108/RAMJ. $03-2021-0922$
Received 20 March 2021 Revised 31 May 2021 Accepted 27 June 2021 
RAMJ

17,1

assets and financial performance proxied by Tobin's Q (Cho et al., 2019). Timely implementation of CSR is very important to enhance a firm's sustainability and firm's value (Machmuddah et al., 2020). CSR performance of an organization is a key aspect to increase firm's financial performance proxied by return of assets (ROA), return of equity (ROE) and Tobin's Q (TQ) (Shu and Chiang, 2020; Aswani et al., 2021). Further, it reveals that CSR advertising and disclosures affect corporate legitimacy (Shahab and Ye, 2018).

It is believed that active CSR engagement may increase the operational cost of the company. The firm's increasing awareness of social work has led to the application of CSR initiation, whose application influences on firm's diverse means of CSR marketing, both at the firm's strategic and operational levels (Zatwarnicka-Madura et al., 2019). As CSR is a growing concern, it is believed that some critic's view on CSR is largely ineffective in perception as a negative influence of business on society and leads to scarcity of public goods (Schneider, 2020). CSR compliance with stakeholder's profitability targets is often in disagreement with the cost engaged input up CSR practices (Sahut et al., 2019; Thottoli, 2021a). Some of the countries made CSR spending and disclosures as mandatory requirements. CSR spending impacts the return of stock which depends on firms merely comply mandatory CSR regulation or voluntarily spending on CSR above the mandated amount (Bhattacharyya and Rahman, 2020). Though many companies actively engage in digital marketing, a significant number of companies not successful in exploiting the full potential of web marketing analytics when assessing digital marketing or advertising strategies (Aberg and Mattsson, 2020). In Gulf Cooperation Council (GCC), organizations should be concerned about paying the Zakat to be an obligation under the Islamic perspective. The spending should constantly be in an ethical way and should give precedence to societal interest over enlarging stakeholders' values (Nurunnabi et al., 2020). There are no organized method and evaluation criteria to the level of effect on their CSR activities in Oman (Al Salmi and Khan, 2019). The level of CSR in United Arab Emirates had the greatest level of CSR compared to the other GCC countries including Oman (Musleh Alsartawi, 2020). The above-mentioned set of challenges motivated the researcher to empirically investigate the relationship of CSR and firm's financial performance in Oman. Therefore, the current study seeks to examine the impact of web marketing on CSR and firms' performance across companies listed in the Muscat Stock Exchange Market (MSX), Oman.

\section{Review of literature}

Companies' website is used to market CSR activities and spending. Tetrevova et al. (2019) assessed the scope of web marketing on CSR and the composition of CSR endeavors communicated by listed companies. Kucukusta et al. (2019) investigated how CSR communications perform by companies through social media as well as which matter, and online channel type gets the maximum level of engagement. El-Bassiouny et al. (2018) aimed to study the concept of CSR communication. The ways of combining operational and strategic levels of CSR web marketing communication were studied by Zatwarnicka-Madura et al. (2019). All the listed companies have a separate section in the company's websites, where CSR strategies are disclosed with headings sustainability or CSR. The classified CSR themes, information related to community commitment themes, and environment themes are mostly highlighted linked with the other classified themes (Briones, 2020). Application of social media for advertising and marketing of products, CSR disclosure practices and stakeholder engagement with financial stakeholders were studied by Troise and Camilleri (2021). The link between firm performance and CSR startups in the banking industry was studied by Prieto et al. (2020).

Currently, the company's website and social links have become useful CSR disclosure tools. It is argued that the asset management company's product information, companies' 
performance and the means to conveys CSR activity messages in the social media might be certainly connected to firm's financial performance (Sciarelli et al., 2020). Business-tobusiness (B2B) organizations are more likely than close-to-market organizations to be involved in the CSR structure and CSR orientation disclosures (Palazzo et al., 2019). In addition, the electronic marketing has a sizable role in the selected industries. Though some firms operated extensively with network analytics to enhance their advertising promotions and social networks, other firms flopped at employing the full possibility of web analytics (Aberg and Mattsson, 2020). It is found that the ownership composition comprising of government ownership and foreign ownership and significantly affected the exercise of CSR disclosure on the organization's websites (Fernando et al., 2019). Graphical and structural emphases about CSR disclosures through certain web-based characteristics improve information fame and could positively impact shareholders' impression of the organization. Investors and shareholders are expected to make investment decisions in favor of the organization, ensuing in a greater share turnover with an improved market value of the stock of the firm (Chong and Rahman, 2020). It is evident that web marketing advertising tools moderated the link between corporate social responsibility and sustainable production of the company (Abbas et al., 2019).

As per the review of the literature about web marketing (through company's website) on CSR and firms' performance across companies listed in the MSX, the current study has developed the below framework (Figure 1) to illustrate the web marketing on CSR and firms' performance proxied by ROA, ROE and TQ.

\section{Methodology}

This research analyses qualitative and exploratory data taken from companies' website, annual reports (the financial year 2019), Google search and CSR report from 69 out of 117 total listed companies in the MSX to analyze the impact of web marketing on corporate social responsibility and firms' performance proxied by ROA, ROE and TQ.

The study as its first step has surfed the website of all the 69 companies to see web marketing on CSR. Aberg and Mattsson (2020), Thottoli (2021b) and Tetrevova et al. (2019) was used web marketing to examine companies' web analytics when marketing their CSR disclosure initiatives. Second and finally, the study was taken financial information from

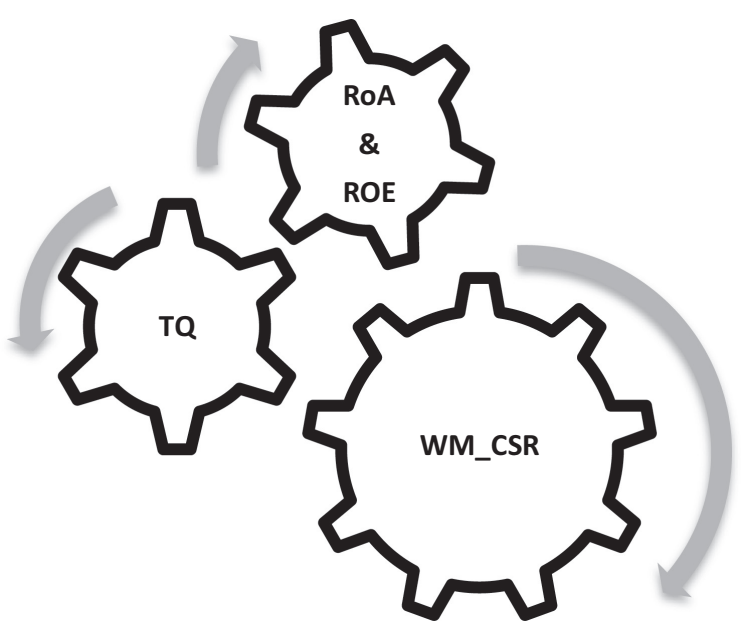

Impact of web marketing on CSR
Figure 1. Web marketing on CSR and firms' performance 
RAMJ

17,1

40

published annual reports (the financial year 2019) of 69 companies from MSX to find out the ROA, ROE and TQ ratios, which have further used to examine the impact of financial performance using curviliant graphical method. Previous studies used several indicators to measure the financial performance of the firm. Among them, based on the previous literature, frequently used measures of the financial performance of any firm were taken as ratios which are calculated based on items in the financial statements and its market values (Thottoli, 2021c). Sichigea et al. (2021) used graphical analysis methods to study the connection between environmental materiality measures and a firm's financial performance. CSR and its relationship to a firm's financial performance are illustrated by using graphical comparison (Turcsanyi and Sisaye, 2013). The variables used with measurements of web marketing and firm's performance were described as below, Table 1 .

\section{Discussion and conclusion}

\subsection{Web marketing on CSR}

Recent studies in web marketing on CSR (Namely, Sarkar et al., 2021; Masoud and Vij, 2020; Lan et al., 2021; Yim et al., 2019) were used to validate the results of the current study on the impact of web marketing on CSR and firms' performance. Most of the previous studies were agreed that web marketing on CSR positively and significantly affects firm financial performance (Seok et al., 2020; Jang et al., 2019).

The below Table 2 shows CSR activities of companies, surfing by companies' website and or published annual report of 2019 signifies descriptive results that the companies listed in MSX were engaged in various CSR activities. Table 2 shows details of the number of selected listed companies, web marketing on CSR (WM_CSR) and CSR activities of companies. Some of the involved CSR activities were disclosed in the company's website are community developmental activities; supported universities; helping in road safety, cancer and elderly people; protecting the environment; initiatives taken to consistently strive for general wellbeing of communities; improvement of quality of workforce their families; sponsorship to sports events, arts exhibition and cultural events; sports, health, safety and environment; support the repair and restoration efforts for the damages caused by Cyclone Mekunu; providing training to number of job seekers in the parent company and its subsidiaries; contributions toward charitable organizations; sponsorship participation in Talented Child initiative; procurement of goods from Oman; supports regional schools; payment for social welfare program; commitment to protect the safety and foster convenience of customers; installing solar power in schools in Oman; involved in COVID-19 relief activities; involved in first-of-its-kind "Kaderoon" Forum which focused on the training, rehabilitation and employment of people with disabilities; providing career opportunities; helping children care center; clean-up initiative at Wadi Al Khoud; contribution to the national economy; donation

\begin{tabular}{lll}
\hline Variables & Acronym & Measurement/Description \\
\hline $\begin{array}{l}\text { Dependent variable } \\
\text { (1) Return on assets }\end{array}$ & & \\
(2) Return on equity & ROA & Net income/Total assets \\
(3) Tobin's Q & ROE & Net income/Total equity \\
& TQ & Market value of equity + Book value of debt/Book \\
& & value of total assets
\end{tabular}

Table 1.

Measurements of the variables

\section{Independent variables}

(1) Web marketing on corporate social responsibility
WM_CSR Marketing on CSR in companies website (0 if no web marketing, 1 if web marketing) 
Selected listed companies

\begin{tabular}{cc}
\hline 1 & Yes \\
2 & Yes \\
3 & Yes \\
4 & Yes \\
5 & Yes \\
& \\
6 & Yes \\
7 & Yes \\
8 & Yes \\
9 & Yes
\end{tabular}

10

11
WM_CSR CSR activities of companies

Yes Community developmental activities, assistance to building of schools, mosques and support for local sports and cultural activities

Supported the Sultan Qaboos University, Economic Research Forum. Celebrating the Spirit of Ramadan, the company has extended support to a number of charity associations during the Holy Month of Ramadan

CSR strategy is underpinned in safe secured world, thriving communities and responsible business. Road safety, cancer and elderly people Protecting the environment, providing economic opportunities and strengthening communities

CSR initiatives are to consistently strive for general well-being of communities. The company continues to support initiatives from nongovernmental organizations and institutions

Improvement of quality of workforce their families and public community The company has contributed toward National Day Celebrations, sponsorship to sports events, arts exhibition and cultural events CSR is interwoven into our business model and enshrined in our dedicated CSR policy called "Our commitments"

We share a common desire to continuously grow and become the pioneers in innovation using cutting edge technology for pipes and structural products. Meeting and exceeding the aspirations of customers, employees and shareholders remains our core focus and a guiding principle for growth

Yes Guided by its CSR policy focusing on local initiatives in the areas of education, sports, health, safety and environment

Company's support to the citizens to various campaigns including Dhofar and Wusta governorates to support the repair and restoration efforts for the damages caused by Cyclone Mekunu that hit southern part of Oman CSR and sustainability strategy pursued by company is focused on delivering long-term benefits to the community and the nation, creating a positive impact on society covering areas such as education, SMEs, youth, sports, alternative energy and health

Company continues to collaborate with local, regional and international stakeholders to affect change, resulting in collaborations with non-profit organizations, municipalities and ministries across the different regions in the Sultanate

Its consistent focus on community welfare through a very active CSR program

Based on the company's responsibility to support locai community services, a number of initiatives have been taken up that meet the needs of the community by training a number of job seekers in the parent company and its subsidiaries

The company has contributed every year toward various charitable organizations

CSR include sponsorship participation in The Talented Child initiative at Salalah Festival in 2016, sponsoring participation in a summer program for students at Al Saidia school and inviting post graduate engineering students from local universities for training and development Set aside amount for CSR toward various charitable organizations CSR for education and training

Procurement of goods from Oman and subcontracts as part of CSR

CSR policy and supports regional schools, sports activities, municipal and other social causes. Company has also invested substantially in preserving and maintaining its environment

(continued)
Impact of web marketing on CSR 
RAMJ 17,1
Selected listed companies WM_CSR CSR activities of companies
No

No

Yes
No

No

Contribute to building a safe, secure and progressive society; promote environmental conservation at all levels; create a culture of giving within the organization; our CSR policy has been divided into two broad categories: the community and the environment, and a three-fold strategy has been developed to address the same, this includes: identification of impacted areas and development of sustainability programs identifying strategic partners to provide support

Yes Our CSR initiatives and programs are reflective of our commitment to keeping the local Omani community at the forefront of our business Payment for social welfare program, proposes for 2020 as CSR policy

Yes

Yes

Yes The company acknowledges its responsibility toward contributing to the community, stemming from its strong belief that the society at large is the reason for the success of company

As part of its ongoing commitment to support the society and environment, company has embarked on number of CSR initiatives and programs related to its mandate and operating field as part of its commitment to protect the safety and foster convenience of customers Yes Contribution toward the society and working for the welfare of the society forms part of the core corporate values of your company

Yes

Yes

Yes Company is working toward installing solar power in schools in Oman mainly in the Musandam Governate to be completed by the end of 2021 The CSR charter is in place and management have made necessary plans for CSR, as approved by your board

Continue donating to charities, sponsoring socio-health related activities, recycling and getting involved in other related tasks to promote a better Oman

Yes

Yes

Yes Company also involved in COVID-19 relief activities as CSR policy Company backed the first-of-its-kind "Kaderoon" Forum which focused on the training, rehabilitation and employment of people with disabilities Company continues to remain committed to providing career opportunities and training to Omani staff to prepare them to assume higher responsibilities

Yes

Yes

Yes

Helping students and children care center as CSR policy

As part of its commitment to the community, company organized a cleanup initiative at Wadi Al Khoud company has always been committed toward contribution to the national economy and the local society in general

Yes In its commitment to CSR initiatives, Oman Cement has been making available, charitable, donation to the society though its philanthropic culture

Yes

Company has well-defined CSR policy, goals and objectives, whose principles are based on the following elements: accountability, transparency, ethical behavior, responsible to stakeholder's interest, respect for the rule of the law, respect for the international norms of

Yes $\quad$ behavior and respect for human rights policy

The company will continue serving the local communities and addressing their needs by supporting the unfortunate individuals with special needs on a focused-segment approach. As per our CSR policy

Table 2. 

Selected listed
companies

43

44

45

46
WM_CSR CSR activities of companies

Yes The "Basmat KHeer" continued its diversified CSR efforts including support of charity organizations, people with special needs, visiting hospitals, productive families and other activities

Yes $\quad$ SME development is a main pillar of company CSR

Yes As a responsible corporate citizen, we see business success and the needs of citizens and communities as inextricably linked to drive and achieve progress

Yes The company has been an active corporate citizen and regularly supports various initiatives focusing on environment preservation, education, social and suitability development

Yes In CSR our "company goodwill” activities included the inauguration of two digital entertainment rooms for the paediatric cancer and surgery wards at the Royal Hospital in Muscat, for the children to enjoy while undergoing treatment; reflecting our spirit and value of "caring"

Supports SMEs in Oman as CSR policy

Yes

Yes

As part of its ongoing commitment to support the society and environment, company has embarked on number of CSR initiatives and programs and has extended its support to various organizations and events

Yes Based on the board's belief with the necessity to participate in social responsibility programs and in accordance with the directives of Capital Market Authority

Yes The company has initiated several activities: education and training health and safety environmental community

Yes Company recognizes its responsibility to the local community. Company strives to establish itself as a good corporate citizen in the community while respecting the values and cultural heritage of the society

Yes An expansion project is under way at Renaissance Village Duqm, the employee accommodation facility in the Special Economic Zone at Duqm (SEZAD)

No

No

Yes

Yes

Based on the Board of Directors' belief in the importance of social contribution to the local community

Focusing on education, health and safety, social development and environment protection. Sohar Power was able to contribute to local projects intended for the local communities and the people of the Sultanate of Oman

Yes To enhance the social, environmental and economic development of the local community we use stakeholder engagement to gain a real understanding of local issues, helping to enhance our positive impact Company wants to be a responsible corporate citizen. Our CSR policy focuses on initiatives in the areas of society, environment, and economy with sustainability at the heart

The company plans and executes projects and runs facilities to create sustainable social value by focusing on Omani talent development, working with local suppliers and contractors, and setting a good example through business practices and ethics as well as maintaining high standards of health, safety, security and environment

Our definition of CSR is simple: we believe that every business, and every individual within those businesses, has a responsibility to make the future a better place

The company has contributing to the local Dhofar region in which it operates as well as segments of communities requiring support 


\begin{tabular}{|c|c|c|c|}
\hline $\begin{array}{l}\text { RAMJ } \\
17,1\end{array}$ & $\begin{array}{l}\text { Selected listed } \\
\text { companies }\end{array}$ & WM_CSR & CSR activities of companies \\
\hline \multirow[b]{3}{*}{44} & 62 & Yes & Improvement and maintenance of local government infrastructure \\
\hline & 63 & Yes & $\begin{array}{l}\text { Focus in Health, education, environment, sports and assisting other } \\
\text { socially important initiatives are major spheres of our social responsibility } \\
\text { program }\end{array}$ \\
\hline & 64 & Yes & \multirow{4}{*}{$\begin{array}{l}\text { CSR initiatives is to consistently strive for general well-being of } \\
\text { communities } \\
\text { Contributing to the community in the areas of education and health } \\
\text { Company is committed to its social responsibility toward the community } \\
\text { Company takes its role as a responsible corporate citizen seriously. Over } \\
\text { the years, the company has actively supported local community bodies, } \\
\text { schools, and charity organizations. Valuing the importance of the youth of } \\
\text { Oman in future progress of the country, the company considers education } \\
\text { as a cornerstone }\end{array}$} \\
\hline & 65 & Yes & \\
\hline & 66 & Yes & \\
\hline & 67 & Yes & \\
\hline & 68 & Yes & $\begin{array}{l}\text { As part of its CSR initiatives, company provides employment to fresh } \\
\text { Omani graduates and diploma holders and imparts training to groom } \\
\text { them as productive resources }\end{array}$ \\
\hline Table 2. & 69 & No & No \\
\hline
\end{tabular}

to the society though its philanthropic culture; elements as responsible to stakeholder's interest, respect for the rule of the law, respect for the international norms of behavior, respect for human rights; Ramadan; activities included the inauguration of two digital entertainment rooms for the pediatric cancer and surgery wards at the royal hospital in Muscat; participate in social responsibility programs and in accordance with the directives of CMA; respecting the values and cultural heritage of the society; providing employee accommodation facility in the Special Economic Zone at Duqm; focusing on Omani talent development, working with local suppliers and contractors; improvement and maintenance of local government infrastructure and provides employment to fresh Omani graduates and diploma holders and imparts training to groom them as productive resources. Sixty-five companies (94\%) out of sixty-nine total sample companies were disclosed CSR marketing activities through their websites.

\subsection{Firms financial performance proxied by ROA, ROE and TQ}

The analysis was extended to know the financial performance of the selected companies proxied by the ROA, ROE and TQ. Below Table 3, a summary of firms financial performance proxied by ROA, ROE and TQ; and Table 4, firms financial performance proxied by ROA, ROE and TQ results were assessed as per the measurement description provided by Table 1 above. The data collected for calculating ROA, ROE and TQ for all the 69 companies listed in MSX were taken from the published annual report of the year 2019. Sixty-five companies (94\%) out of sixty-nine total sample companies were disclosed CSR marketing activities through their websites.

Table 3.

Summary of firms financial performance proxied by ROA, ROE and TQ

\begin{tabular}{llllllll}
\hline & \multicolumn{2}{c}{ ROA } & \multicolumn{2}{c}{ ROE } & \multicolumn{2}{c}{ TQ } \\
Total No. of companies & No & $(+\mathrm{ve})$ & $(-\mathrm{ve})$ & $(+\mathrm{ve})$ & $(-\mathrm{ve})$ & $(+\mathrm{ve})$ & $(-\mathrm{ve})$ \\
\hline Disclosed WM_CSR & 65 & 53 & 12 & 53 & 12 & 65 & 0 \\
Percentage (\%) & $100 \%$ & $82 \%$ & $18 \%$ & $82 \%$ & $18 \%$ & $100 \%$ & $0 \%$
\end{tabular}




\begin{tabular}{|c|c|c|c|c|c|}
\hline Co & WM_CSR & $\mathrm{ROA}$ & ROE & TQ & Impact of web \\
\hline 1 & Yes & 0.06 & 0.31 & 1.90 & CSR \\
\hline 2 & Yes & 0.01 & 0.13 & 1.01 & \\
\hline 3 & Yes & 0.05 & 0.10 & 1.39 & \\
\hline 4 & Yes & 0.09 & 0.10 & 1.84 & \\
\hline 5 & Yes & 0.01 & 0.01 & 1.25 & \\
\hline 6 & Yes & $(0.17)$ & $(0.25)$ & 0.89 & 45 \\
\hline 7 & Yes & 0.01 & 0.05 & 0.97 & \\
\hline 8 & Yes & 0.01 & 0.04 & 2.00 & \\
\hline 9 & Yes & 0.00 & 0.01 & 0.47 & \\
\hline 10 & Yes & 0.04 & 0.12 & 0.88 & \\
\hline 11 & Yes & 0.01 & 0.06 & 1.01 & \\
\hline 12 & Yes & 0.02 & 0.09 & 1.07 & \\
\hline 13 & Yes & 0.01 & 0.07 & 0.83 & \\
\hline 14 & Yes & 0.01 & 0.10 & 1.00 & \\
\hline 15 & Yes & $(0.24)$ & $(0.09)$ & 4.46 & \\
\hline 16 & Yes & 0.01 & 0.02 & 0.53 & \\
\hline 17 & Yes & $(0.01)$ & $(0.08)$ & 1.12 & \\
\hline 18 & Yes & $(0.11)$ & $(0.36)$ & 1.59 & \\
\hline 19 & Yes & 0.20 & 0.25 & 3.95 & \\
\hline 20 & Yes & $(0.07)$ & $(0.45)$ & 0.26 & \\
\hline 21 & Yes & 0.04 & 0.08 & 1.82 & \\
\hline 22 & No & $(0.10)$ & $(0.22)$ & 1.42 & \\
\hline 23 & No & 0.01 & 0.09 & 1.05 & \\
\hline 24 & Yes & 0.01 & 0.05 & 1.06 & \\
\hline 25 & Yes & $(0.00)$ & $(0.00)$ & 1.47 & \\
\hline 26 & Yes & $(0.01)$ & $(0.04)$ & 1.02 & \\
\hline 27 & Yes & 0.00 & 0.01 & 0.94 & \\
\hline 28 & Yes & 0.04 & 0.05 & 1.02 & \\
\hline 29 & Yes & 0.03 & 0.08 & 0.92 & \\
\hline 30 & Yes & 0.03 & 0.27 & 1.11 & \\
\hline 31 & Yes & 0.04 & 0.06 & 5.56 & \\
\hline 32 & Yes & $(0.02)$ & $(0.11)$ & 0.36 & \\
\hline 33 & Yes & 0.09 & 0.14 & 0.88 & \\
\hline 34 & Yes & 0.01 & 0.09 & 1.01 & \\
\hline 35 & Yes & 0.02 & 0.09 & 1.09 & \\
\hline 36 & Yes & 0.06 & 0.18 & 1.55 & \\
\hline 37 & Yes & 0.01 & 0.11 & 1.41 & \\
\hline 38 & Yes & 0.05 & 0.07 & 0.97 & \\
\hline 39 & Yes & 0.01 & 0.02 & 0.96 & \\
\hline 40 & Yes & $(0.24)$ & $(0.35)$ & 1.42 & \\
\hline 41 & Yes & 0.05 & 0.07 & 1.88 & \\
\hline 42 & Yes & 0.00 & 0.01 & 1.03 & \\
\hline 43 & Yes & 0.02 & 0.08 & 0.30 & \\
\hline 44 & Yes & 0.04 & 0.07 & 0.84 & \\
\hline 45 & Yes & 0.02 & 0.08 & 1.02 & \\
\hline 46 & Yes & 0.10 & 0.13 & 1.48 & \\
\hline 47 & Yes & 0.08 & 0.13 & 1.65 & \\
\hline 48 & Yes & 0.01 & 0.02 & 0.76 & \\
\hline 49 & Yes & 0.04 & 0.11 & 0.53 & \\
\hline 50 & Yes & 0.04 & 0.13 & 0.69 & \\
\hline 51 & Yes & $(0.02)$ & $(0.06)$ & 0.87 & \\
\hline 52 & Yes & 0.00 & 0.00 & 1.09 & \\
\hline 53 & Yes & 0.10 & 0.27 & 1.11 & Table 4. \\
\hline 54 & No & 0.10 & 0.12 & 1.87 & Firms financial \\
\hline & & & & (continued) & $\begin{array}{r}\text { performance proxied } \\
\text { by ROA, ROE and TQ }\end{array}$ \\
\hline
\end{tabular}




\begin{tabular}{|c|c|c|c|c|c|}
\hline & & & & & \\
\hline $\begin{array}{l}\text { KAIVI } \\
171\end{array}$ & Co & WM_CSR & ROA & ROE & $\mathrm{TQ}$ \\
\hline & 55 & Yes & 0.03 & 0.05 & 0.92 \\
\hline & 56 & Yes & 0.01 & 0.10 & 0.89 \\
\hline & 57 & Yes & $(0.00)$ & $(0.01)$ & 1.45 \\
\hline & 58 & Yes & 0.27 & 0.27 & 1.02 \\
\hline & 59 & Yes & 0.07 & 0.20 & 1.63 \\
\hline 46 & 60 & Yes & 0.02 & 0.03 & 2.15 \\
\hline & 61 & Yes & 0.05 & 0.09 & 2.10 \\
\hline & 62 & Yes & 0.04 & 0.13 & 1.33 \\
\hline & 63 & Yes & 0.03 & 0.11 & 0.83 \\
\hline & 64 & Yes & 0.14 & 0.15 & 2.26 \\
\hline & 65 & Yes & 0.02 & 0.09 & 1.05 \\
\hline & 66 & Yes & 0.03 & 0.04 & 1.34 \\
\hline & 67 & Yes & $(0.01)$ & $(0.02)$ & 0.69 \\
\hline & 68 & Yes & 0.01 & 0.02 & 1.06 \\
\hline Table 4. & 69 & No & 0.02 & 0.10 & 1.11 \\
\hline
\end{tabular}

As per Tables 3 and 4, 53 companies (82\%) resulted with +ve ROA (Figure 2), 53 companies $(82 \%)$ resulted with +ve ROE (Figure 3$)$ and 65 companies $(100 \%)$ resulted with +ve TQ (Figure 4).

Accordingly, the research findings were provided evidence on the result which has positively and significantly impact web marketing (through the company's website) on CSR and firms' performance across companies listed in the MSX, Oman. The current findings agree with those given by Sciarelli et al. (2020) and Tetrevova et al. (2019), who proposed that increased marketing of CSR activities electronically by companies will positively affect a firm's financial performance. Finally, it is suggested that CSR spending should make as a compulsory provision to all the listed companies in Oman. In the future, if CSR spending (say, $0.5 \%$ on profit after tax) made compulsory, as per generally accepted accounting principles (GAAP) can enable firms or companies to determine automatically by information communication technology (ICT) enabled accounting, auditing and compliance (Thottoli, 2020a, b, 2021d; Thottoli et al., 2019a, b, c; Thottoli and Thomas, 2020).

\section{Implications for future research}

The current study contributes to both theoretical as well as practical implications for the board of directors and practitioners.

Theoretically, this research study contributed to examine the extensive use of web marketing on CSR communication, which might lead to expect that this study might consider furthering studies. Future researchers could use distinct methodologies and sampling frames to further examine this subject matter widely. The prospective researchers can examine the customers' perceptions and thoughts toward web marketing relating to CSR information of public/private companies. Future research in web marketing might inquire greater into various indicators arising from different web marketing channels including social media. Further empirical studies could extend in different contexts, including businesses in different industrial sectors and entrepreneurial new startups.

Practically, this research contributed firstly to clarify that web marketing is an important platform for communicating CSR. Hence, web marketing might be applied for various other promotional activities, including product promotion and publicizing CSR activities among customers and other stakeholders. Second, the study deepens insight if we are marketing CSR. Further, the research findings provide new insights that are able to enlighten governing 


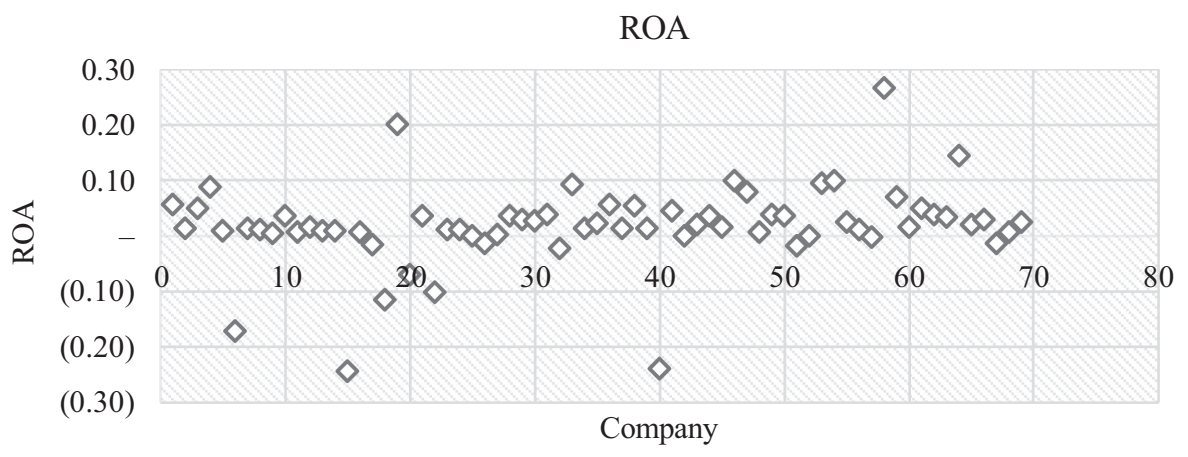

Impact of web marketing on CSR

Figure 2.

Return of assets

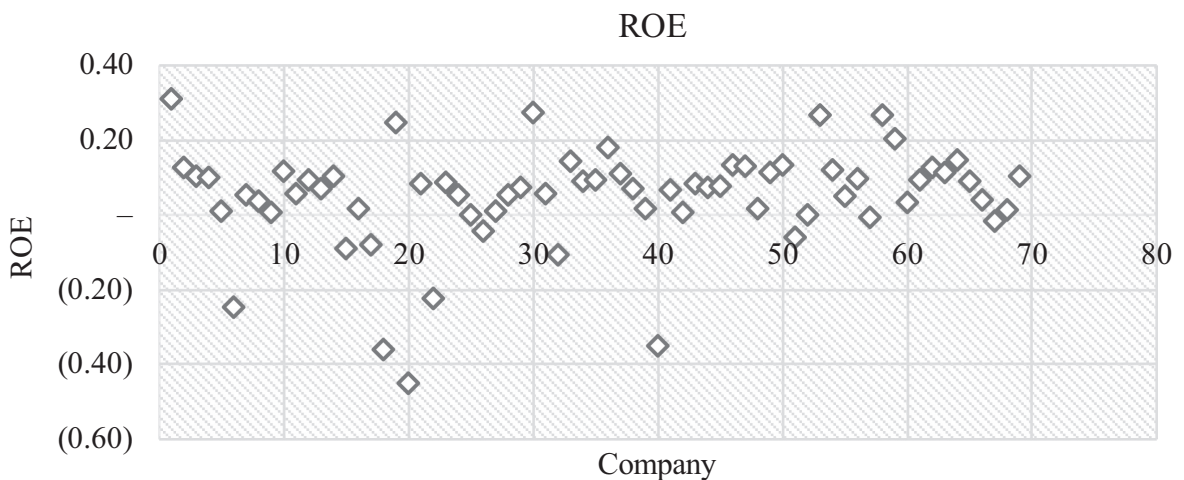

Figure 3. Return of equity

TQ

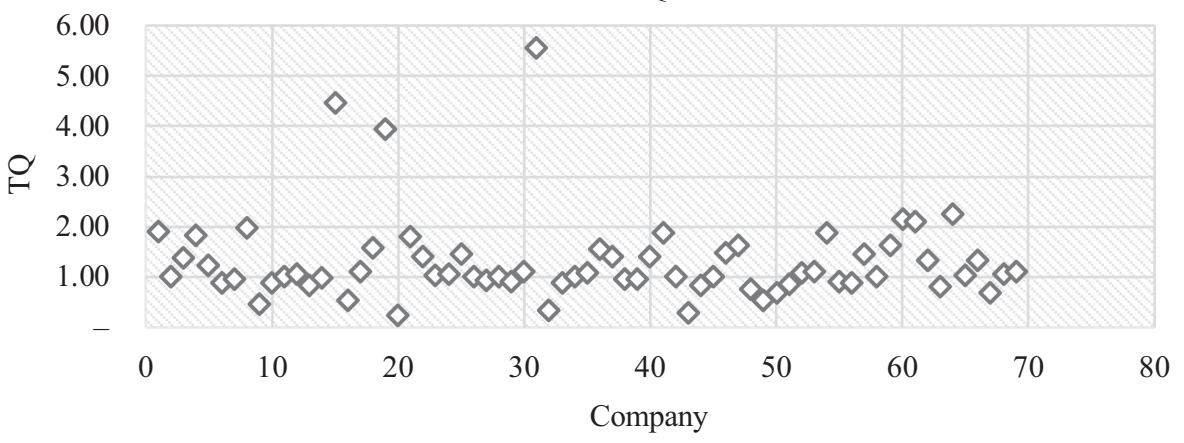

Figure 4. Tobin's Q

bodies in Oman to make standardized compulsory CSR spending (say, $0.5 \%$ on profit after tax) by listed companies in MSX. The proposed $0.5 \%$ on profit after tax contribution to CSR was helped to suggest by the study results. The results of the study can be useful for the board of directors of the company to decide on emphasizing web marketing on CSR more innovatively to enhance the firm's financial performance. Web marketing on CSR by listed companies may inspire private and unlisted companies to involve engagement in voluntary social activities that all may result in the firm's financial performance. 
RAMJ

17,1

\section{Conclusion}

This research presents evidence that web marketing on CSR can increase firms' performance and brand image among stakeholders. This is the first study to examine the impact of web marketing on CSR and firms' performance using empirical data in Oman. Web marketing on CSR positively affects firms' performance. Especially, the positive effect of web marketing on firms' performance is stronger for listed companies. Web marketing enhances financial performance proxied by ROA, ROE and TQ. Another fascinating part of the study that, out of 69 companies, only one company has decided to set aside an amount equal to $0.75 \%$ on profit after tax each year. This has considered as a strong support to the author's recommendation to make CSR spending a compulsory provision to all the listed companies in Oman.

\section{Limitations}

The study has some limitations. Only limited variables (ROA, ROE and TQ) have been taken for measuring the financial performance of the selected companies. In the future, the research studies can consider other variables such as firm size, type of industry and composition of the board to further analyze the firm's financial performance.

\section{References}

Abbas, J., Mahmood, S., Ali, H., Ali Raza, M., Ali, G., Aman and Nurunnabi, M. (2019), "The effects of corporate social responsibility practices and environmental factors through a moderating role of social media marketing on sustainable performance of business firms", Sustainability, Vol. 11 No. 12 , p. 3434.

Åberg, M. and Mattsson, F. (2020), How CSR Is Marketed and Optimized in the Swedish Fashion Industry: A Qualitative Study on Digital Marketing and Web Analytics When Marketing CSR.

Al Salmi, H. and Khan, F.R. (2019), "A comparative case study on accountability of corporate social responsibility (CSR) practices in Oman Lng and Omifco at Sur city in Oman”, Humanities and Social Sciences Reviews, Vol. 7 No. 5, pp. 490-502.

Aswani, J., Chidambaran, N.K. and Hasan, I. (2021), "Who benefits from mandatory CSR? Evidence from the Indian companies act 2013”, Emerging Markets Review, Vol. 46, p. 100753.

Bhattacharyya, A. and Rahman, M.L. (2020), "Mandatory CSR expenditure and stock return”, Meditari Accountancy Research, Vol. 28 No. 6, pp. 951-975.

Boğan, E. and Dedeoğlu, B.B. (2019), "The effects of hotel employees' CSR perceptions on trust in organization: moderating role of employees' self-experienced CSR perceptions", Journal of Hospitality and Tourism Insights, Vol. 2 No. 4, pp. 391-408.

Briones, J.P. (2020), "Online CSR disclosures of Philippines' top 30 publicly-listed companies”, International Journal of Business and Society, Vol. 21 No. 1, pp. 63-78.

Cho, S.J., Chung, C.Y. and Young, J. (2019), "Study on the relationship between CSR and financial performance", Sustainability, Vol. 11 No. 2, p. 343.

Chong, S. and Rahman, A. (2020), "Web-based impression management? Salient features for CSR disclosure prominence", Sustainability Accounting, Management and Policy Journal, Vol. 11 No. 1, pp. 99-136.

El-Bassiouny, N., Darrag, M. and Zahran, N. (2018), "Corporate Social Responsibility (CSR) communication patterns in an emerging market: an exploratory study", Journal of Organizational Change Management, Vol. 31 No. 4, pp. 795-809.

Fernando, K., Sambuaga, E.A., Kurniawan, B., Riswandari, E. and Bwarleling, T.H. (2019), "CSR web reporting: a new communication technology tool for corporate reporting and its relation with ownership structure", 1st International Conference on Life, Innovation, Change and Knowledge (ICLICK 2018), Atlantis Press, Bandung, pp. 27-32. 
Jang, S.S., Ko, H., Chung, Y. and Woo, C. (2019), "CSR, social ties and firm performance”, Corporate Governance, Vol. 19 No. 6, pp. 1310-1323.

Kucukusta, D., Perelygina, M. and Lam, W.S. (2019), "CSR communication strategies and stakeholder engagement of upscale hotels in social media", International Journal of Contemporary Hospitality Management, Vol. 31 No. 5, pp. 2129-2148.

Lan, T., Chen, Y., Li, H., Guo, L. and Huang, J. (2021), "From driver to enabler: the moderating effect of corporate social responsibility on firm performance", Economic Research-Ekonomska Istraživanja. doi: 10.1080/1331677X.2020.1862686.

Machmuddah, Z., Sari, D.W. and Utomo, S.D. (2020), "Corporate social responsibility, profitability and firm value: evidence from Indonesia", The Journal of Asian Finance, Economics, and Business, Vol. 7 No. 9, pp. 631-638.

Masoud, N. and Vij, A. (2020), "The effect of mandatory CSR disclosure on firms: empirical evidence from UAE”, International Journal of Sustainable Engineering, pp. 1-12, doi: 10.1080/19397038. 2020.1821405 (accessed 2 March 2021).

Musleh Alsartawi, A. (2020), "Does it pay to be socially responsible? Empirical evidence from the GCC countries", International Journal of Law and Management, Vol. 62 No. 5, pp. 381-394.

Nurunnabi, M., Alfakhri, Y. and Alfakhri, D.H. (2020), "CSR in Saudi Arabia and Carroll's Pyramid: what is 'known' and 'unknown'?", Journal of Marketing Communications, Vol. 26 No. 8, pp. 874-895.

Özcan, F. and Elçi, M. (2020), "Employees' perception of CSR affecting employer brand, brand image, and corporate reputation", SAGE Open, Vol. 10 No. 4, p. 2158244020972372.

Palazzo, M., Vollero, A., Foroudi, P. and Siano, A. (2019), "Evaluating constitutive dimensions of CSR e-communication: a comparison between 'Business-To-Business' and 'Close-To-Market' companies", Journal of Business-to-Business Marketing, Vol. 26 Nos 3-4, pp. 341-355.

Prieto, A.B.T., Shin, H., Lee, Y. and Lee, C.W. (2020), "Relationship among CSR initiatives and financial and non-financial corporate performance in the Ecuadorian banking environment", Sustainability, Vol. 12 No. 4, p. 1621.

Sahut, J.M., Peris-Ortiz, M. and Teulon, F. (2019), "Corporate social responsibility and governance", Journal of Management and Governance, Vol. 23 No. 4, pp. 901-912.

Sarkar, S., Chatterjee, M. and Bhattacharjee, T. (2021), "Does CSR disclosure enhance corporate brand performance in emerging economy? Evidence from India", Journal of Indian Business Research, Vol. ahead-of-print No. ahead-of-print, doi: 10.1108/JIBR-06-2019-0201.

Schneider, A. (2020), "Bound to fail? Exploring the systemic pathologies of CSR and their implications for CSR research", Business and Society, Vol. 59 No. 7, pp. 1303-1338.

Sciarelli, M., Tani, M., Landi, G. and Turriziani, L. (2020), "CSR perception and financial performance: evidences from Italian and UK asset management companies", Corporate Social Responsibility and Environmental Management, Vol. 27 No. 2, pp. 841-851.

Seok, J., Lee, Y. and Kim, B.-D. (2020), "Impact of CSR news reports on firm value”, Asia Pacific Journal of Marketing and Logistics, Vol. 32 No. 3, pp. 644-663.

Shahab, Y. and Ye, C. (2018), "Corporate social responsibility disclosure and corporate governance: empirical insights on neo-institutional framework from China", International Journal of Disclosure and Governance, Vol. 15 No. 2, pp. 87-103.

Shu, P.G. and Chiang, S.J. (2020), "The impact of corporate governance on corporate social performance: cases from listed firms in Taiwan”, Pacific-Basin Finance Journal, Vol. 61, p. 101332.

Sichigea, M., Siminica, M., Cristea, M., Noja, G.G. and Circiumaru, D. (2021), "Materiality conditions in the interplay between environment and financial performance: a graphical modeling approach for EEA Oil and gas companies", Complexity, 2021.

Impact of web marketing on CSR 
RAMJ

17,1

Srivastava, G. (2019), "Impact of CSR on company's reputation and brand image", Global Journal of Enterprise Information System, Vol. 11 No. 1, pp. 8-13.

Tetrevova, L., Patak, M. and Kyrylenko, I. (2019), "Web-based CSR communication in post-communist countries”, Applied Economics Letters, Vol. 26 No. 10, pp. 866-871.

Thottoli, M.M. (2020a), "Knowledge and use of accounting software: evidence from Oman", Journal of Industry-University Collaboration, Vol. ahead-of-print No. ahead-of-print, doi: 10.1108/JIUC-042020-0005 (accessed 2 March 2021).

Thottoli, M.M. (2020b), "Impact of accounting software among SMEs accountants in Oman", Financial Markets, Institutions and Risks, Vol. 4 No. 2, pp. 25-33, doi: 10.21272/fmir.4(2).2533.2020.

Thottoli, M.M. (2021a), “The relevance of compliance audit on companies' compliance with disclosure guidelines of financial statements", Journal of Investment Compliance, Vol. ahead-of-print No. ahead-of-print, doi: 10.1108/JOIC-12-2020-0047 (accessed 2 March 2021).

Thottoli, M.M. (2021b), "The interrelationship of marketing, accounting and auditing with corporate social responsibility", PSU Research Review, Vol. ahead-of-print No. ahead-of-print, doi: 10.1108/ PRR-12-2020-0045 (accessed 2 March 2021).

Thottoli, M.M. (2021c), "Impact of information communication technology competency among auditing professionals", Accounting Analysis Auditing, Vol. 8 No. 2, pp. 38-47, doi: 10.26794/ 2408-9303-2021-8-2-38-47.

Thottoli, M.M. (2021d), "Practical knowledge in preparing financial statements and ICT-enabled financial plans: an empirical study among entrepreneurial students in Oman”, International Entrepreneurship Review, Vol. 7 No. 1, pp. 21-31, doi: 10.15678/IER.2021.0701.02.

Thottoli, M.M. and Thomas, K.V. (2020), "Characteristics of information communication technology and audit practices: evidence from India", VINE Journal of Information and Knowledge Management Systems, Vol. ahead-of-print No. ahead-of-print, doi: 10.1108/VJIKMS-04-2020-0068 (accessed 2 March 2021).

Thottoli, M.M., Thomas, K.V. and Ahmed, E.R. (2019a), "Qualitative analysis on information communication technology and auditing practices of accounting professionals", Journal of Information and Computational Science, Vol. 9 No. 9, available at: https://www.researchgate.net/ profile/Essia_Ahmed/publication/337428182_Qualitative_Analysis_on_Information_ Communication_Technology_and_Auditing_Practices_of_Accounting_Professionals/links/ 5dd6ebd8299bf10c5a26bc20/Qualitative-Analysis-on-Information-Communication-Technologyand-Auditing-Practices-of-Accounting-Professionals.pdf (accessed 10 February 2020).

Thottoli, M.M., Thomas, K.V. and Ahmed, E.R. (2019b), “Adoption of audit software by audit firms: a qualitative study", Journal of Information and Computational Science, Vol. 9 No. 9, pp. 768-776.

Thottoli, M.M., Thomas, K.V. and Ahmed, E.R. (2019c), "Examining the impact of information communication technology on auditing professionals: a quantitative study", Journal of Advanced Research in Dynamical and Control Systems, Vol. 11, pp. 476-488, available at: https:// www.jardcs.org/.

Troise, C. and Camilleri, M.A. (2021), "The use of digital media for marketing, CSR communication and stakeholder engagement", in Camilleri, M.A. (Ed.), Strategic Corporate Communication in the Digital Age, Emerald Publishing, Bingley, pp. 161-174.

Turcsanyi, J. and Sisaye, S. (2013), "Corporate social responsibility and its link to financial performance: application to Johnson \& Johnson, a pharmaceutical company", World Journal of Science, Technology and Sustainable Development, Vol. 10 No. 1, pp. 4-18.

Yim, S., Bae, Y.H., Lim, H. and Kwon, J. (2019), "The role of marketing capability in linking CSR to corporate financial performance: when CSR gives positive signals to stakeholders", European Journal of Marketing, Vol. 53 No. 7, pp. 1333-1354. 
Zatwarnicka-Madura, B., Siemieniako, D., Glińska, E. and Sazonenka, Y. (2019), "Strategic and operational levels of CSR marketing communication for sustainable orientation of a company: a case study from Bangladesh”, Sustainability, Vol. 11 No. 2, p. 555.

\section{Corresponding author}

Mohammed Muneerali Thottoli can be contacted at: muneerali@unizwa.edu.om 